\title{
<提言〉
}

\section{糖尿病者の脳・心血管病予防をめざしたリスク管理研究 （J-DOIT3）－問題点の指摘および追跡研究への提言}

\author{
奥山治美 ${ }^{1)} *$ 、浜六郎 ${ }^{2)}$ 、大櫛陽一 ${ }^{3)}$ 、浜崎智仁 ${ }^{4)}$ 、内野元 ${ }^{5)}$ \\ Critical Examination of the Problems Associated with the \\ J-DOIT3 study and a Proposal for its Follow-up Study, an \\ Intensified Intervention in Diabetics with Hypertension and \\ Dyslipidemia
}

\author{
Harumi Okuyama ${ }^{1) *}$, Rokuro Hama ${ }^{2)}$, Yoichi Ogushi ${ }^{3)}$, \\ Tomohito Hamazaki ${ }^{4}$, Hajime Uchino ${ }^{5)}$
}

\section{Summary}

An open-label, randomized controlled trial in type 2 diabetics with hypertension, dyslipidemia, or both was reported (J-DOIT3 study). The participants were randomly assigned to receive conventional or intensive therapy with respect to HbAlc, blood pressure and LDL-C ( $n=1,271$ in each group), and were followed for 8.5 years at 81 clinical sites. Both the participants and doctors in charge were aware of the group assigned. The experimental design was essentially as recommended in the [Comprehensive risk management chart for the prevention of cerebro- and cardiovascular diseases 2015] from the Joint Committee consisted of 13 internal medicine-related societies in Japan, and the Japan Atherosclerotic Society Guidelines 2017. Therefore, the conclusion from the J-DOIT3 study is expected in medical field to affect the current and future medications for the prevention of atherosclerotic cerebro- and cardiovascular diseases (ASCVD). While analyzing the results of this study, we encountered serious problems associated with the methodology, logics and its interpretations, which were summarized in this review. The follow-up study appears to be in progress as described in the Discussion, but we interpret that the intensive therapy used in the J-DOIT3 study is risky in view of currently available evidence. We propose the authors of the study to let the participants know of the results on its objective endpoint, and newly obtain Informed Consents including the potential risks of the intensive intervention based on the progress in this field after the start of this study.

Keywords: diabetics, dyslipidemia, hypertension, hyperglycemia, J-DOIT3 study キーワード : 糖尿病者・高脂血症・高血圧・高血糖・J-DOIT3 研究 
略 号: J-DOIT3, Japan Diabetes Optimal Integrated Treatment study for 3 major risk factors of cardiovascular diseases

1) 名古屋市立大学、金城学院大学、 ${ }^{2)}$ 医薬ビジランスセンター、 ${ }^{3)}$ 大櫛医学情報研究所、 ${ }^{4}$ 富山大学、 理化学研究所、富山城南温泉第二病院、 ${ }^{5}$ 医療法人 内野会

1) Nagoya City University, Kinjo Gakuin University, NGO Council for the Safety Evaluation of Fats and Oils in Foods

2) NPO Japan Institute of Pharmacovigilance (NOPJIP), Osaka

3) Ogushi Institute of Medical Informatics, Kanagawa

4) Toyama University, Institute of Physical and Chemical Research (RIKEN), and Toyama Jonan Onsen Daini Hospital, Toyama

5) Medical Coorporation Uchinokai, Kumamoto

*, 1-89 Kaminokura, Midoriku, Nagoya 458-0812, Japan

* \% 458-0812 名古屋市緑区神の倉 1-89

電話：052-876-3840 FAX：052-876-3840 Email : okuyamah@kinjo-u.ac.jp

糖尿病者を対象とし、高脂血症、高血 圧、高血糖を主危険因子とした脳・心血 管病予防研究 (J-DOIT3) の結果が報告 された ${ }^{1)}$ 。この研究は日本内科医学会な ど 13 医学会からなる合同委員会の「脳 心血管病予防に関する包括的リスク管理 チャートについて2015」 ${ }^{2)}$ (以下、包括 リスク管理 2015 と略す）および日本動脈 硬化学会の「動脈硬化性疾患予防ガイド

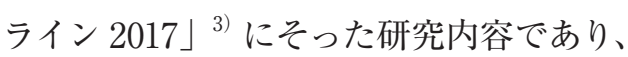
その成果は、今後、わが国の糖尿病、動 脈硬化性脳心血管病 (ASCVD)、高血圧 などの医療指針に影響を与えるものと注 目されている ${ }^{4)}$ 。

しかし最近のこの分野の進歩にてらし て、この論文には多くの問題があり ${ }^{5-10)}$ 、そ の結果はむしろ「包括リスク管理 2015」 を否定するものであったと解釈できる。 本稿はこれらの問題を批判的にまとめた 総説である。J-DOIT3 研究には、このま まの内容で追跡を継続すると記述されて いるが ${ }^{1)}$ 、研究開始以降のこの分野の進
歩にてらして研究参加者の不利益につな がる危険性が高い。この研究の追跡を継 続するためには、その強化療法に付随す る危険性を含む新たなインフォームドコ ンセントを得るよう提案する。

以下の記述は J-DOIT3 研究の翻訳で はなく、著者の解釈、コメントなどが含 まれている。

\section{使われた研究方法 ${ }^{1)}$}

対象者は 45-69 歳の 2 型糖尿病者で高 脂血症、高血圧症あるいは両方をもつ患 者であり、非遮蔽 RCT 方式で行われた。 患者は通常療法群と強化療法群にランダ ムに振り分けられ (各群 1,271 名)、血糖 (HbAlc)、血圧、LDL-C を指標として全 国 81 施設で 8.5 年間(中央值) 介入された。 この研究では、患者も担当医も 2 群のど ちらに属するかを知らされていた。した がって、合併症発症の判断に担当医の主 観が入る余地があり、評価項目（アウト 
Table 1 The data were taken from the J-DOIT3 study ${ }^{1)}$, and were summarized in this table under our responsibility.

\begin{tabular}{|c|c|c|c|c|c|c|c|c|}
\hline \multirow[b]{2}{*}{ 群 } & \multicolumn{3}{|c|}{ 介入中の指標 } & \multicolumn{2}{|c|}{ 主評価項目 } & \multicolumn{3}{|c|}{ 事後解析* } \\
\hline & $\begin{array}{c}\mathrm{HbA} 1 \mathrm{c}, \\
\%\end{array}$ & $\begin{array}{l}\text { 血圧, } \\
\mathrm{mmHg}\end{array}$ & $\begin{array}{l}\mathrm{LDL}-\mathrm{C} \text {, } \\
\mathrm{mg} / \mathrm{dL}\end{array}$ & $\begin{array}{l}\text { 心筋梗塞. } \\
\text { 脳卒中 } \\
\text { イベント数 }\end{array}$ & $\begin{array}{l}\text { 総死亡例 } \\
\text { 数 }\end{array}$ & $\begin{array}{l}\text { 心筋梗塞 } \\
\text { 脳卒中・血 } \\
\text { 行再建率 } \\
\text { イベント数 }\end{array}$ & $\begin{array}{l}\text { 冠動脈 } \\
\text { イベン数 }\end{array}$ & $\begin{array}{l}\text { 脳血管 } \\
\text { イベント数 }\end{array}$ \\
\hline 通常療法 & 7.2 & $129 / 74$ & 104 & 88 & 48 & 133 & 55 & 42 \\
\hline 強化療法 & 6.8 & $123 / 71$ & 85 & 65 & 49 & 109 & 48 & 18 \\
\hline $\mathrm{HR}$ & - & - & - & 0.74 & 1.01 & 0.81 & 0.86 & 0.42 \\
\hline $\mathrm{p}$ 值 & & 0.0001 & & 0.055 & 0.95 & 0.094 & 0.44 & 0.002 \\
\hline
\end{tabular}

*, 例数が予測值に達しなかったため、途中で血行再建率を追加して解析した。その結果を、事後解析の欄にまとめた。 HR, ハザード比

カム）の客観性が重要問題となる。

Primary Outcome : 複合アウトカムであ り、総死亡と心筋梗塞、冠動脈バイパス 手術、経皮経管腔冠血管形成術、脳卒中、 頸動脈内膜切除率、経皮的冠動脈形成術 および頸動脈ステント術のいずれかが発 生するまでの期間であった。血行再建術 は冠動脈バイパス術、経皮的冠動脈形成 術および頸動脈ステント術を含んでいる。 研究遂行の途中 (3 年目) でアウトカム を変えたので、事後 (Post-hoc) 解析と なる。

Main Secondary Outcome : 総死亡 率および心筋梗塞、脳卒中のイベント 数。これは当初の Main Outcomeであっ たが、 3 年経過時にイベント数が大幅に 予測值を下回ったため、血行再建術を加 えて上記の Primary Outcome とし、当 初の Main Outcome を Main Secondary Outcome と名前を変えた（原報 p.954, Outcomes and Statistics の項参照)。

\section{J-DOIT3 研究の結果}

介入目標は通常療法群対強化療法群で
それぞれ、 $\mathrm{HbAlc}$ 值：<6.9 対 $<6.2(\%)$ 、 血圧 : $<130 / 80$ 対 $<120 / 75(\mathrm{mmHg})$ 、 LDL-C 值 : < 120 対 < $80(\mathrm{mg} / \mathrm{dL})$ 、 ただし、冠疾患のある場合は $<100$ 対 $<$ 70）であった。介入の結果達成された両 群の各指標の值と、主要アウトカム数、 ハザード比（HR）を Table 1 にまとめた。

\section{J-DOIT3 研究の問題点}

（1）糖尿病、高脂血症、高血圧、心・脳 血管病のあいだの因果関係・相互関係は 明確でない。これらの因子を持つ対象者 に、3種の薬物療法、および各種の生活習 慣変容という多因子について介入し、か つ 81 臨床センターの関わる介入試験であ るため変数が多すぎてバイアスがかかり やすく、得られた結果がいずれの介入に よる影響かの解釈が困難で結論を出し難 い研究計画であったと判断する。たとえば スタチンで LDL 值を下げると糖尿病が新 規発症し、そのメカニズムも解明されてき ているとき ${ }^{7-10)}$ 、他の脳・心血管リスクを 持つ人を含めて試験の対象とすることは、 論理性に欠ける。 
（2）糖尿病の治療では合併症を予防し、 最終的に延命することが最も重要な治療 目標となる。 2 型糖尿病患者にインスリ ンを 1 日 3 回以上注射して HbAlc を平 均 $7.0 \%$ に維持できた群 (MIT, multiple insulin treatment, 52 人) では、1〜2回 注射で HbAlc が平均 $9 \%$ 台であった群 (CIT, conventional insulin treatment, 50 人）と比較して 6 年追跡後、合併症を予 防できたが、死亡率の低下は不明であっ た（死亡者は 6 年間でMIT 群 2 人、CIT 群 1 人） ${ }^{11)}$ 。1 2 回注射群の HbAlc が 平均 $9 \%$ 台（当初 $9 \%$ 、後半約 10\%）で あるのは、一般的な 1 ～回法のインスリ ン療法の結果 (8\%台) ${ }^{12,13)}$ と比較して、 コントロールが不良であったと解釈でき る。

一方 ACCORD 研究では、 2 型糖尿病 患者にインスリン（約 30\%）、メトホルミ ン（約 $60 \%$ )、SU 剂（約 $50 \%$ )、グリ夕 ゾン剤（約 $20 \%$ ）を用いて HbAlc を平 均 6.4\%に低下させた強化療法群は、同平 均 $7.5 \%$ を維持した標準療法群に比較して、 低血糖発作が有意に多く、心血管疾患死 亡のハザード比は 1.35、総死亡のハザード 比は、1.22であった (いずれも有意) ${ }^{14)}$

ICUに入院した重症患者を対象とし て、高血糖のインスリンによる厳格なコン トロールの影響を評価した RCT 中、最も 大規模かつ最も適切な計画で行われた試 験（NICE-SUGAR study）においても同

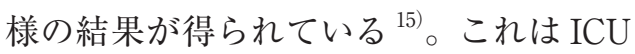
に入院した重症患者 6,104 人を対象として 実施された。通常療法群では、血糖值が $180 \mathrm{mg} / \mathrm{dL}$ を超えたときにインスリン注
射（点滴）が使われ、144 mg/dL 未満に なれば減量ないし中止し平均 140 台（中 央值 $142 \mathrm{mg} / \mathrm{dL}$ ）で推移した。強化療法 群では血糖值を 81 〜 108mg/dL の間にな るように同様にインスリン注射 (点滴) が 行われ、平均 110 台 (中央值 $107 \mathrm{mg} / \mathrm{dL}$ ) で推移した。血糖值が $40 \mathrm{mg} / \mathrm{dL}$ 以下の 重度低血糖発作の発症率は、通常療法群 が $0.5 \%$ に対して強化療法群では $6.8 \%$ と有 意に高かった（オッズ比 14.7、95\%信頼区 間 9.0-25.4、 $\mathrm{p}<0.001)$ 。90 日後の死亡者の 割合は、通常療法群 $24.9 \%$ に対して $27.5 \%$ と強化療法群で有意に高かった（オッズ比 1.14、95\%信頼区間 1.02-1.28、p = 0.02） ${ }^{15) 。 ~}$ 上記試験 ${ }^{15)}$ における重症低血糖を起こ した例の、低血糖を起こさなかった例に対 する 90 日目の死亡のハザード比は 1.4 2.4 であった ${ }^{16)}$ 。2 型糖尿病においても同 様に、低血糖による死亡危険度の増加が 報告されている。ACCORD 試験 ${ }^{14)}$ の解 析（3.5 年間で中断）では、低血糖例の死 亡ハザード比は $1.4 〜 2.3$ であった ${ }^{17)}$ 。他 の報告でも 10 年間における死亡ハザード 比 (propensity score, 調整) は 2.48 と報 告されている ${ }^{18)}$ 。

これらを考慮して、日本（日本糖尿病学 会：科学的根拠に基づく糖尿病診療ガイ ドライン 2013） や米国（ADA Standards of Medical Care in Diabetes 2018) の糖 尿病学会のガイドラインでは HbAlc の治 療目標を $7.0 \%$ 未満としているが、この目 標值でも低すぎると考える。

J-DOIT3 の強化療法で HbA1cを 6.2\% 未満としているのは極めて危険である。 
その証拠に、強化療法群で低血糖発作 が約 2 倍に増えている（p<0.0001 Table 2)。米国糖尿病学会では薬物開始基準は、 HbAlc が 9.0\%までは生活習慣改善を主と しており、薬剤を使うとしてもメトホルミ ンのみとしている（ただし、日本人でメト ホルミンが本来適応になる BMI 值が 30 超の人は極めてまれである)。J-DOIT3 の 対象者の平均 HbAlc はベースラインで、 強化療法群が $8.01 \pm 1.05 \%$ 、通常療法群 が $7.98 \pm 1.05 \%$ あり、いずれの群でも $9.0 \%$ 未満の人が $65 \%$ 程度を占めると推測 される。それにもかかわらず両群ともに目 標 HbAlcに達しない場合には、BMI 值 25 以上でメトホルミン、その他は SU 剤 や DPP-4 阻害剤、GLP-1 作動剤、インス リン注射を使った。これも極めて危険な医 療である。米国糖尿病学会では、HbAlc が $6.5 \%$ 未満を目標とすることも認めてい るが、生活習慣改善とメトホルミンのみ」、 「心血管系疾患の無い人」、「低血糖発症な どの副作用が無い人」という条件が付け られている ${ }^{16,19)}$ 。あるいはメトホルミンは、 BMI が 30 超のヒトでインスリン過剩の人 にのみ限定すべきである ${ }^{17,20)}$

J-DOIT3 では、通常療法群と強化療法 群とも低血糖発作が $22 \%$ と $41 \%$ と高い率 で発生しており、浮腫やクレアチニン上昇 も少なくない。いずれも強化療法群で有 意に高い発生率となっているので、治療 強度との用量 - 反応関係も見られている。

（3）当初の endpoints で有意性を示すイ ベント数が集まらなかったため、血行再建 術を加えた pot-hoc analysis に切り替えら
れた。しかし英米の「臨床研究に関わる 新規制、2004/2005 年」以降、この手法に 伴うバイアスに注目されている。とくにこ の研究の場合、open-label 方式であった ため、担当医の主観が入る可能性が高く、 血行再建術を客観性の高い指標とは認め がたい。したがって、 post-hoc analysis の結果のみに基づきこの強化療法を続行 することは ${ }^{1)}$ 、正当化できない。とくにそ の強化療法の内容の論理性に問題がある ときは、outcomeの客観性に留意するこ とが求められる。

（4）生活習慣の変容が糖尿病指標に及ぼ す効果は、J-DOIT3 (Fig.2 F) と同様に 一過性であり、しかも長期的に糖尿病合 併症を抑えることには成功していない。工 ネルギー摂取制限の栄養指導の内容が重 要であり、脂質を単にエネルギーとして 扱っている場合は多くの場合、植物油脂 / 動物性脂肪の摂取比を上げる結果となっ ている。この指導が逆に糖尿病を促進し、 ASCVDを増やすことが明らかにされつつ ある ${ }^{5,6)}$ 。したがって、この強化療法で使 われた食事指導を脂質栄養の面から再検 討することが求められている。

一方、禁煙や、アルコールを日本酒 1 合換算以下に厳密に抑えることなど、血 糖值のコントロールに直接は無関係である が、総死亡や、脳卒中イベントを抑えうる 要因が強化療法群のみに強力に介入され ており、これが強化療法群の総死亡の抑 制傾向に貢献した可能性がある。このよ うな場合、薬物以外の要因、とくに飲酒と 喫煙については多変量調整して、イベント 
発症危険度を求める必要がある。イベン 卜発症の危険度については、感度分析と して、これらの要因を調整したハザード比 を求めているが、総死亡については、飲 酒と契煙などに関して多変量調整した感 度分析を実施していない。

強化療法群でこれらの要因への介入が なかったならば、強化療法によって、総 死亡は増えていた可能性が否定できない。 また、総死亡率や ASCVD イベントに差 がないが、脳血管系イベントは強化療法 群で有意に少なかった (Fig.2)。このこと は、「強化療法群で有意に多かったイベン トが隠されている可能性」を推測させる。

（5）上述の欧米での新規制の発効以来、 相対リスクと絶対リスクの使い分けが厳 格になった。脳血管イベントの HR が 0.42 であるが、「強化療法群のイベントが $58 \%$ 少なかった」、という表現は、相対リスク 低下に基づいている（Fig.3, E)。通常治

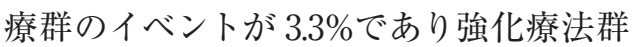

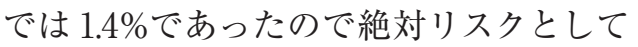
は $1.9 \%$ の低下であり、相対リスク低下と しての $(1.9 / 3.3) \times 100=58 \%$ の強調は不 適切とされている。眓示する場合も一般 に、縦軸を 0-100\%とした図が同時に示さ れる。この点は、とくに一般向け解説書で は留意する必要がある ${ }^{1)}$ 。

（6）有意差の認められた脳血管イベント数 が血行再建術を加えても 18 例と 42 例と 極めて少ないため、 $\mathrm{p}$ 值が小さくても信頼 性は高くなく、また post-hoc analysis の 結果であり、予備試験的な結果であると
理解すべきではないか。ちなみに降圧薬 により脳梗塞が増えるエビデンスがいくつ かの大規模試験や住民コホート研究で示 されており、LDL-C 值の高い方が脳梗塞 発症率は低く、発作後の予後が良いこと や、スタチンが脳出血を増やすメカニズム が明らかにされている。「脳血管イベント を予防するためにこの強化療法が有効で ある」とするのは、危険である ${ }^{5)}$ 。

（7）強化療法群は、通常療法群に比較し て Nephropathy が有意に少ない $(\mathrm{HR}=0.68$, $\mathrm{p}<0.0001$ 、Figure 5) ${ }^{1)}$ 。こころ が、 Table 2 では、クレアチニン值上昇者が有 意に多く（6.9\%対 $4.1 \%$ 、オッズ比 1.73 、 $\mathrm{p}=0.0022)$ 、浮腫の出現が有意に多く（15 $\%$ 対 $10 \%$ 、オッズ比 $1.59 、 \mathrm{p}=0.0001$ )、両 者の結果は矛盾している。薬物で過剩に 血圧を下げたり、あるいは低血糖が生じ ると、代償性にアドレナリンなどストレ スホルモンが分泌され、末梢血管の収縮 を招き、血管疾患が発症しやすくなる ${ }^{21)}$ 。 末梢血管の収縮は腎血流を低下させ、腎 機能が低下し、クレアチニン值は上昇し 浮腫が生じうる。また、グリタゾン剂では 浮腫は高頻度に起こる。さらには、ス夕チ ンやワルファリンがビタミン K2- オステオ カルシン連係を阻害して、腎障害をひきお こすメカニズムが明らかにされている ${ }^{8,10) 。 ~}$ 強化療法群で低血糖が多く、血圧がより 低下しているので、これらの結果は、よく 整合している。

一方、Nephropathy については、定義 があいまいであり、遮蔽試験でないために、 強化療法群に好都合に（頻度が低く）診 
断される危険性がある。そして、強化療 法で nephropathy が有意に下がった、と いうデー夕は他の多くの研究と整合しな い $^{22)}$ 。この面からもこの研究の強化療法 を国民に広げることは危険であると考え る。

（8）最初の対象者数（各群 1,271名）か ら除外者数（103 vs. 111, Fig. 1) およ び死亡者数（49 vs. 48）を差し引いた 数 $(1,119$ vs. 1,160$)$ に対して、追跡 8 年以降の Number at riskが著しく少な い $(760$ vs. 750$) 。 こ の$ Fig. 1 と Fig. 3 から消えた人数が多く 1)、観察されたイ ベント数が少ない時は、消えた対象者の 追跡の結果が極めて重要である。また、 Number at risk の変化は、Fig. 3C の All-cause mortality の場合と Fig. 3 の A (Primary outcome)、B (Main secondary outcome)、D (Coronary events)、E (Cerebrovascular events) の場合で無視 できない程度に異なっている。

（9） J-DOIT3 の一般向け解説書 ${ }^{1)}$ では、 強化療法群で網膜症が有意に低下したよ うに図示されているが、関連する JDCS 研 究 $^{23)}$ では網膜症が増える傾向が図示され ているのではないか?

（10）「J-DOIT3 研究は継続中」と Discussion で書かれているが、客観性の 高い指標である総死亡率が両群で全く差 がなかったこと、心筋梗塞・脳卒中のイ ベント数には有意な差が認められないこと は、この包括リスク管理 2015 の適切性に
疑問があることを示し、漫然と継続すべき ではない。スタチン療法では数年後にス タチン治療群、プラセボ一群共にスタチン 服用率が 3 割台に低下していたという観 察があり ${ }^{24)}$ 、両群をそのまま長期に追跡 しても薬物効果の正確な評価ができない ことが指摘できる。

そもそもスタチンが糖尿病を発症させる という臨床データが多くあり、その作用メ カニズムが明らかになっている現在 ${ }^{8,20,25)}$ 、 一体、どのような Informed Consents が 得られているのであろうか?

（11）インクレチン関連剤や SGLT-2 阻害 剤はプラセボとの非劣性のみが示されて いる。ACCORD 試験では、主にメトホル ミン、SU 剂が用いられ、インスリンが 30 \%、グリタゾン剂が 10 数\%で用いられた が、インクレチン関連薬剤（DPP-4 阻害剤、 GLP-1 作動剂）やSGLT-2 阻害剂が用い られて強化療法群と通常療法群が比較さ れた試験はまだない。むしろ、これらの血 糖降下剂は、総死亡はもとより心血管疾 患を減らすことが証明できていない ${ }^{17,20)}$ 。 ロシグリタゾンに至っては、心血管イベン 卜をむしろ増加させた。ACCORD 試験 では血糖值のコントロールが心血管防止 や死亡減少に役立たないことがわかった にも関わらず、米国 FDA の内分泌代謝疾 患用薬剤に関する諮問委員会で、以下の ことが確認された。

（1）心血管イベントの予防には血糖值のコ ントロールが重要、

（2）したがって、HbAlc を承認根拠とす ることは妥当、 
（3）心血管リスク改善を証明することは困 難そうなので、心血管系イベントの改 善を承認の要件とはしない。

しかし、プラセボを対照としたランダム 化比較試験で、ハザード比の 95\%信頼区 間が 1.3 未満を確認する非劣性試験が必 要とされ、承認済みの薬剤についてもこれ を実施することになり、プラセボに比較し て非劣性であることをもって有用とする、 全く通常の感覚が通じない論理で、糖尿 病用の薬剤は使用されている ${ }^{21,26)}$ 。

また、プラセボに対する優越性を証明 したとする、リラグルチド（GLP-1 作動郕） と、エンパグリフロジン（SGLT-2 阻害剂） には、不自然なデータが多く遮蔽不全が 強く疑われるために、実際上、優越性が 証明されているとは言えない ${ }^{17,21) 。 ~}$

\section{結論}

この研究結果は、現行の日本動脈硬化 学会ガイドライン 2017 や内科学会合同委 員会の進める包括的リスク管理 2015 の正 当性を支持していない。この研究の追跡 調査が継続中であると Discussion に記載 されているが、我々は、現在の知見にて らしてこの強化療法は極めて危険な介入 法であったと解釈する ${ }^{8-10,20,27)}$ 。J-DOIT3 の責任者は参加者に客観的指標について の介入結果をしらせ、J-DOIT3 の強化療 法が危険である可能性を説明した新たな インフォームド コンセント得るよう提案す る。

\section{利益相反関係}

本稿の著者には、関連する書籍類の発
行のほかは、開示すべき利益相反は全く ない。

\section{参考文献}

1. Ueki $\mathrm{K}$ et al. Lancet Diabetes Endocrinol. 5:951-64, 2017.

2. 脳心血管病予防に関する包括的リス ク管理合同会議, 日本内科学会雑誌. 104:824-59, 2015.

3. 日本動脈硬化学会編集, 動脈硬化性 疾患予防ガイドライン 2017. 日本動脈 硬化学会発行 (東京) 2017.

4. Care Net, 2017 年 9 月 25 日 / HealthDay News.

http://www.carenet.com/news/ general/hdnj/44717

5. 日本脂質栄養学会監修、長寿のため のコレステロールガイドライン 2010, 中日出版社

6. Hamazaki T et al. Ann Nutr Metab. 66 Suppl 4:1-116, 2015.

7. Okuyama H et al. Expert Rev Clin Pharmacol. 8:189-99, 2015.

8. Okuyama $\mathrm{H}$ et al. Pharmacology. 98:134-70, 2016.

9. 浜崎智仁. オレオサイエンス. 17:58491, 2017.

10. Okuyama $\mathrm{H}$ et al. Pharmacology. 101:184-218, 2018.

11. Ohkubo Y et al. Diabetes Res Clin Pract. 28:103-117, 1995.

12. YM581 研究会、基礎と臨床. 23 (13): 5025-5032, 1989.

13. 早川哲夫、近藤 孝晴、柴田 時宗、他、 プラクティス. 9 (2) : 172-178, 1992.

14. Accord Study Group. N Engl J Med. 358:2545-59, 2008.

15. NICE-SUGAR Study Investigators, 
N Engl J Med. 360:1283-97, 2009.

16. NICE-SUGAR Study Investigators, N Engl J Med. 367:1108-18, 2012.

17. Bonds DE et al BMJ. 340:b4909, 2010.

18. Hsu PF, Sung SH, Cheng HM, et al. Diabetes Care. 36:894-900, 2013.

19. American Diabetes Association. Diabetes Care. 39 (Suppl.1) :S39-S46, 2016.

20. 浜六郎、脂質栄養学. 26:59-74, 2017.

21. Sanon VP et al. Clin Cardiol. 37:499504, 2014.

22. He S-J et al. Therap Clin Risk Manga. 14:475-482, 2018.
23. Sone $\mathrm{H}$ et al. Diabetologia. 53; 419-28, 2010.

24. Diamond D et al. BMJ. 359:j4915, 2017.

25. Ooba $\mathrm{N}$ et al. BMJ Open. 7:e015935, 2017.

26. Editorial、糖尿病用薬剂の評価方法 はなぜ「甘い」, 薬のチェック TIP. 16 (67): 102, 2016.

27. 日本脂質栄養学会、糖尿病 - 生活習 慣病予防委員会、糖尿なのに脂質 (あ ぶら）が主因!」クオリティーケア、 2017. 